\title{
Capital Gain Expectations And Efficiency In The Real Estate Markets
}

Shady Kholdy, California State Polytechnic University, Pomona Ahmad Sohrabian, California State Polytechnic University, Pomona

\begin{abstract}
Capital gain expectation is known to be an important determinant of housing price hikes during the real estate booms. Empirically, however, specifying the way expectations about current and future economic variables are formed is a dilemma. Although it is reasonable to assume that economic fundamentals have a significant effect on the investors' expectation about future gains, a number of housing market analysts claim that expectations of housing prices are extrapolative. This study attempts to investigate the mechanism by which investors' capital gain expectations and psychology are shaped. The results suggest that housing prices are predictable with respect to capital gain expectations only when these expectations are formed by extrapolation of past price appreciations. Considering the large number of empirical evidence on housing market anomaly with respect to capital gain expectations, the results suggest that the extrapolative expectations can better explain the real estate price behavior than expectations that are formed by economic fundamentals.
\end{abstract}

Keywords: Housing markets, housing market efficiency, housing prices.

\section{INTRODUCTION}

hile the majority of available empirical evidence support stock market efficiency, a large number of studies find that the real estate market is predictable with respect to some information. ${ }^{2}$ A number of studies claim that the housing market is described by excessive speculation during booms. These studies maintain that expectation of capital gains can force housing prices to a higher level than their fundamental values; therefore, housing price hikes are primarily caused by investors' expectations and psychology rather than expansions in economic fundamentals.

Abraham and Hendershott (1992, 1996), Case and Shiller (1994) and Meese and Wallace (1994) indicate that during housing booms the expectation of capital gains plays a much more important role in boosting housing demand than economic fundamentals. Riddel (1999) finds speculative bubble in the housing market in Santa Barbara South Coast. Roche (2001) decomposes housing prices in Dublin into fundamental and non-fundamental components. He finds out that ever-increasing housing prices are driven mainly because of the speculative bubble. Ho and Kwong (2002) conclude that speculative activity and property prices are cointegrated. Meese and Wallace (2003) indicate that during 1988-1990 actual prices remained about 20 percent higher than fundamental prices in the Parisian housing market. Dusansky and Koc (2007), on their econometric analysis on Florida's housing market, conclude that homebuyers consider housing as an investment asset with potentials for capital gain rather than consumption good.

If economic fundamentals are not sufficient to explain the sharp housing price movements in economic booms, and these price movements are significantly driven by investors' expectations, then understanding the mechanism by which investors' expectations are built is extremely important in comprehending the housing price behavior. Specifying

2 See Brueggeman, Chen, Thibodeau (1984), Hartzell, Heckman, Miles (1986), Mankiw and Weil (1989), Park, Mullineaux, and Chew (1990), and Scott (1990). 
the way expectations about current and future economic variables are formed, however, is a dilemma.

It is reasonable to assume that economic fundamentals have a significant effect on the investors' expectation about future gains. Nevertheless, a number of housing market analysts claim that expectations of housing prices are extrapolative. Reporting the survey results of four cities, Shiller (1990) points out that expectations are formed by a strong extrapolation of recent local appreciation. Abraham and Hendershott (1992) corroborate that lagged appreciation rates explain a significant part of sharp price run-up in the Northeast in the late 1980s.

The focus of this study is to discern an empirical model that can accurately define investors' capital gain expectations. We try to investigate whether the housing price pattern can be predicted more effectively by an extrapolative capital gain expectations model, or whether it can be predicted more precisely by an expectation model based on economic fundamentals. To our knowledge this paper is the first empirical attempt to test and determine the mechanism by which investors' capital gain expectations and psychology are shaped. In an efficient market, the capital gains expectations should not be able to predict the future price.

To examine the effect of capital gain expectations and economic fundamentals on the housing prices, we apply the Vector Error Correction Model (VECM). The advantages of VECM over conventional estimation procedures are as follows:

1. A simple statistical hypothesis test of causal relations used in most previous literature may not provide a complete description and analysis of the data. The VECM can test the existence and the direction of causality between the time series.

2. The VECM can measure the long-term equilibrium relationship between the variables as well as their reactions to short-term shocks.

3. The VECM allows us to reduce the problem of imposed prior restrictions.

The methodology employed is a two-stage approach. In the first stage, the estimates of "expected" housing prices are generated. In the second stage, using the error correction model, the effect of the "anticipated" prices on the current housing prices is analyzed.

Finally, this study is focused on California. The past two decades proved to be one of the most turbulent times in the U.S. real estate market. However, the housing cycles across states and metropolitan areas were not concurrent. During the1980s, substantial housing price booms occurred in the Northeast, California, and Seattle, while major price declines happened in many parts of Southwest. During the 1990s, the 1980s booms in California and Northeast turned to busts. Therefore, to prevent the effect of housing boom in one area to dilute the effect of housing bust in another area, this study concentrates only on the real estate market of California.

The remainder of this paper is organized as follows: section 2 describes the real estate cycles. Section 3 reviews the empirical framework. Section 4 explains the empirical results, and section 5 draws the conclusion.

\section{REAL ESTATE CYCLES}

Case and Shiller argue (1994, pp. 45), "When housing prices rise as rapidly as they did during the booms described above, the first place economists turn for an explanation is to the fundamentals of supply and demand. It is highly unlikely that such booms could have occurred without strong basic economic forces driving the demand for housing. It is equally unlikely that such booms could have occurred with a highly elastic supply of housing."

The strong housing demand in California in the 1980s can be partly explained by a strong economy. The economy of California was much stronger than that of the nation prior to 1989. The annual growth rate in nominal personal income was 8.2 percent in California compared to 6.5 percent in the United States in the late 1980s. The unemployment rate was 6.2 percent in California compared to 6.5 percent in the United States during the same period. The supply of housing, on the other hand, could not react adequately due to strict zoning rules in California. Compelling 
evidence suggests that "growth control zoning" played an important role in the California's boom in the late 1980s. The strong demand and inadequate supply caused housing caused another housing boom in California in 2000s.

Despite the influence of a strong economy, increasing evidence suggests that the expectations of capital gains and speculative behavior of homebuyers might have played a more important role in the housing market boom. Many economists are convinced that fundamentals alone were insufficient to explain the extent of price increase. They believe that the greedy land speculators willingly paid the significantly higher prices because of the anticipation of higher capital gain in future. As a result, these studies presume that housing market is predictable with respect to capital gain expectations.

Abraham and Hendershott argue that economic fundamentals are not sufficient to explain the observed changes in Freddie Mac price indexes for the Northeast in the mid 1980s and California in the late 1980s (1992, pp. 39-40): “.... The inability to explain the sharp price movements in the Northeast... is especially troublesome. Only one-third of the extraordinary run-up in the Northeast in the middle 1980s is explained...Part of this seems to be speculative bubble; using the observed, rather than stimulated, lagged appreciation rate explains another quarter of the increase."

Case (1986) finds a similar result for Boston, and reports that despite a growing economy, market "fundamentals" cannot explain the rapid increase in housing prices in the Boston area since 1983. He posits that housing market behavior is more consistent with the asset price theories previously used to explain the price "bubbles" in the financial market.

Case and Shiller show that the housing market price movements in California and Boston present significant evidence of an expectation-driven run-up (1994, pp. 46): "An efficient asset market should behave like a random walk, reacting instantaneously to new information. The picture of asset prices smoothly accelerating and decelerating over a four-year period is exactly the opposite of what efficient markets theory suggests. When prices were rising rapidly, everyone "knew" that owning was a smart move; and all homeowners earned extraordinary returns except, of course, those who bought at or near the peak." They maintain that (pp. 46) "the fact that prices have since collapsed in both Boston and Los Angeles adds weight to the argument that part of the explanation for the boom lies outside the fundamentals."

\section{THE EMPIRICAL FRAMEWORK}

Directly observed expectations are rare; therefore, one of the most important issues when estimating models with expectations is to specify the mechanism by which the public forms its expectations about future economic variables.

To examine the expectation structure that can explain the predictability of housing prices with respect to capital gain expectation, we test the market efficiency under two assumptions:

1) Expected prices are determined by economic fundamentals like real interest rates, real income, real housing prices of the previous period, employment, and population.

2) Expected prices are determined mainly by past appreciation rates and seasonal adjustments.

\subsection{The Model}

In an efficient market, all the relevant available information is quickly absorbed, and the past information does not provide any predictable influence on the housing prices. To test the efficiency of the real estate market, we examine the causal relationship between past information and current prices applying the cointegration with Vector Error Correction Model. (VECM). 
The VECM provides a comprehensive test of causality. It specifically allows us to: (1) examine the long-term relationship between the time series, and (2) test the existence and direction of causality. ${ }^{3}$

The (n x 1) vector $x_{t}=\left(x_{1 t}, x_{2 t}, \ldots, x_{n t}\right)$ has an error-correction representation if it can be expressed in the form:

$$
\Delta x_{t}=\pi_{0}+\pi x_{t-1}+\pi_{1} \Delta x_{t-1}+\pi_{2} \Delta x_{t-2}+\ldots \ldots+\pi_{p} \Delta x_{t-p}+\varepsilon_{t},
$$

where $\pi=$ a matrix with elements $\pi_{\mathrm{jk}}$ such that one or more of the $\pi_{\mathrm{jk}}$ are not equal to zero. Solving the above equation for $\pi \mathrm{x}_{\mathrm{t}-1} \square \square$ which is the error correction representation of variables in $\mathrm{x}_{\mathrm{t}}$, yields:

$$
\pi x_{t-1}=\Delta x_{t}-\pi_{O}-\sum \pi_{i} \Delta x_{t-i}-\varepsilon_{t}
$$

Let all variables in $\mathrm{x}_{\mathrm{t}}$ be integrated of degree $1 \mathrm{I}(1)$, then if variables in $\mathrm{x}_{\mathrm{t}}$ are co-integrated, $\pi \mathrm{x}_{\mathrm{t}-1}$ must be stationary. Since $\pi$ contains only constants, each row of $\pi$ is a cointegrating vector of $x_{t}$. The key feature in the VECM is the presence of matrix $\pi$. The absence of the Granger causality for cointegrated variables requires: 1) current changes in variable I to be independent of the past changes in variable $\mathrm{J} ; 2$ ) all the $\pi_{\mathrm{jk}}$, speed of adjustment coefficients, to be equal to zero. Thus the VECM allows for $\mathrm{x}_{\mathrm{j}}$ to Granger cause variable $\mathrm{x}_{\mathrm{i}}$, even if the coefficients on lagged changes in $\mathrm{x}_{\mathrm{j}}$ are not jointly significant.

\subsection{Variables And Data}

The empirical analysis of this paper uses monthly data during January 1986 to December 2002. The key variables of our analysis are: real median price of single family houses in California (Price), number of civilian population employed in California (Emp), real interest rates, real income, and population.

California labor force statistics and California consumer price indices were obtained from the U.S. Department of Labor, Bureau of Labor Statistics. The data on income, population, and interest rates, as measured by the S\&L cost of funds in the 11th District (Rate), were collected from the California Department of Finance. Finally, the data on median price of single-family houses in California were gathered from the California Statistical Abstract published by the California Department of Finance. The data on population were available only in annual series. The monthly growth rates were calculated for different years and were applied to estimate the monthly population series.

The cointegration with error correction model requires all data series to be generated by a covariance stationary process. To check the stationarity of each of the variables, Augmented Dickey and Fuller (1979) tests of unit roots were applied. All of the variables were covariance stationary after first differencing.

\section{EMPIRICAL RESULTS}

To find out which expectation model can better explain the predictability of housing prices, the vector error correction model is estimated separately for each expectation model. The fitted values of the two expectation models are replaced for the expected prices in the VECM.

3 For a detailed discussion of cointegration with error correction model, see Engel and Granger (1987), and Engl. And Yoo(1987). 


\subsection{Market Efficiency And Expectations Formed By Fundamentals}

Table 1 reports the estimates of expected prices as a function of the economic fundamentals. The high adjusted$\mathrm{R}^{2}(0.64)$ indicates that the model captures most of the dispersion of the real housing prices. Although insignificant, lagged real prices and real interest rates are kept in the equation for their predictive power. Other variables are all significant. From an econometric view, the fitted values can be used as instrument variables that either contain no measurement errors, or contain measurement errors that are uncorrelated with measurement errors of the realized values, and thus can help to obtain consistent estimates of the parameters of the system.

In the second stage of the estimation, the fitted values of the above model, used as expected prices, along with real housing prices, real interest rates, and employment were employed to estimate the VECM. Real income and population series are excluded for two reasons: (1) to preserve degrees of freedom; (2) the high correlation between these series and employment.

To apply the VECM, time series have to be cointegrated. Cointegration necessitates the variables to be integrated of the same order. The Augmented Dickey-Fuller test is applied to infer the order of integration. All variables are determined to be $\mathrm{I}(1)$.

To test the cointegration of the time series, the Johansen (1988) likelihood estimator is applied. ${ }^{4}$ Table 2 presents the results of the Johansen cointegration tests. The results indicate that series are cointegrated. Cointegration among the time series justifies the use of the VECM.

Table 3 reports the results of causality tests based on the error correction model. The first column in the Table shows the error correction (speed of adjustment) terms and the $t$ values. The results indicate that the error correction terms are significant for price, expected price and employment, implying that in response to a previous period's deviation from long run equilibrium, all three variables change concurrently. Furthermore, the magnitude and sign of error correction terms suggest that price expectations adjust with the same speed as real prices.

Columns two through five of Table 3 present the log-likelihood ratios, testing the joint significance of the lagged coefficients against the specified system. The insignificant log-likelihood ratio of expected price, reported in the first row, indicates that available information on the expected prices cannot predict the real housing prices. Therefore, the housing market seems to be efficient with respect to expected prices when expectations are formed by fundamentals.

This finding suggests that capital gain expectation models that are mainly based on economic fundamentals cannot explain the expectation-driven run-ups in housing prices that are reported by Case and Shiller (1988a, 1988b, 1994), and others. The results show that the housing market is also efficient with respect to available information on employment. The log-likelihood ratio of 65.11 for employment, however, rejects the null hypothesis that past values of real interest rates do not have any effect on the real housing prices implying that available information on real interest rates is useful in predicting the real housing prices.

4 The results of Johansen test are sensitive to the selected lag length. To judge the model adequacy against over and under fitted versions, the log-likelihood ratio test statistics is followed. The appropriate lag length is determined to be twelve. Results are available from the authors upon request. 
Table 1

Expected housing price based on economic fundamentals

Regression of real prices on change of lagged real prices, change in real interest rates, real income, employment and population. Numbers in parenthesis show t-values. Fitted values of this regression are replaced as instruments for the future expected prices in the VECM to obtain consistent estimated of the parameters of the system.

$\begin{array}{ll}\text { Constant } & -3610.83^{*} \\ & (-7.7) \\ \text { Lagged real price } & 0.402 \\ & (1.53) \\ \text { Real interest rates } & -16.11 \\ & (-1.05) \\ \text { Real income } & 0.01^{*} \\ & (10.43) \\ \text { Employment } & 0.37 * \\ & (14.38) \\ \text { Population } & 0.00006^{*} \\ & (3.6) \\ \text { Adjusted } \mathrm{R}^{2} & 0.64\end{array}$

(*) denote the rejection of the null hypothesis of no effect at $5 \%$ level of significance.

Table 2

Johansen Cointegration Test

Expected prices are based on fundamentals.

\begin{tabular}{ccc}
\hline $\begin{array}{c}\text { Likelihood } \\
\text { Ratio }\end{array}$ & $\begin{array}{c}\mathbf{5} \text { percent Hypothesized } \\
\text { Critical value }\end{array}$ & No. Of cointegrating vectors \\
\hline 96.62 & 62.99 & None** \\
62.87 & 42.44 & At most $1^{* *}$ \\
31.31 & 25.32 & At most $2^{* *}$ \\
9.60 & 12.25 & At most 3 \\
\hline
\end{tabular}

** Denotes rejection of the hypothesis at 5\% significance level. The null hypothesis of at most three cointegrating vectors cannot be rejected at 5\% level. Therefore, Likelihood Ratio test indicates 3 cointegrating equations at 5\% level. 
Table 3

Temporal, Causality Tests from Error Correction Model with Expectation Based on Fundamentals

The estimated error correction terms and log likelihood values to determine the efficiency in real estate market with respect to information on expected prices, real interest rates, and employment. The first column in the table shows the error correction terms and the $t$ values. Columns two through five present log-likelihood ratios, testing the hypothesis that past values of variable I do not have any effect on the $\mathrm{J}$.

Lagged values of changes in

\begin{tabular}{|c|c|c|c|c|c|}
\hline \multirow{2}{*}{ Equations } & & & & & \\
\hline & $\mathrm{EC}$ & $\begin{array}{l}\text { Real housing } \\
\text { prices }\end{array}$ & $\begin{array}{l}\text { Expected real } \\
\text { housing prices }\end{array}$ & $\begin{array}{l}\text { Real } \\
\text { interest rates }\end{array}$ & Emp \\
\hline Real housing prices & $\begin{array}{l}-0.084 \\
(-3.90)\end{array}$ & ------- & 26.32 & $65.11 * *$ & 14.10 \\
\hline Expected prices & $\begin{array}{l}-0.087 \\
(-2.51)\end{array}$ & $32.79 * *$ & --------- & $63.71 * *$ & $61.36 * *$ \\
\hline Real interest Rate & $\begin{array}{l}0.0003 \\
(0.77)\end{array}$ & $32.85 * *$ & $108.48 * *$ & --------- & $43.37 * *$ \\
\hline Employment & $\begin{array}{l}-0.172 \\
(-2.76)\end{array}$ & $82.03 * *$ & $36.60 * *$ & $28.36 * *$ & ---------- \\
\hline
\end{tabular}

Note: $* *$ indicates the rejection of the null hypothesis at $5 \%$ level of significance.

\subsection{Market Efficiency And Extrapolative Price Expectations.}

Concluding that expectation models that are based on economic fundamentals are not consistent with the housing price behavior evidence, we proceed by testing the assumption that expected prices are mainly determined by past appreciation rates and seasonal adjustments.

Table 4 reports the estimates of the extrapolative model. To forecast the expected real housing prices, the real price appreciation rates of the last three months and monthly dummy variables are adopted as independent variables. The higher orders of lagged real price appreciation rates are insignificant and reduce the adjusted $\mathrm{R}^{2}$.

The fitted values of the extrapolative expected prices along with the other variables (real housing prices, real interest rates, and employment) were employed to reexamine the VECM model.

To test the cointegration of the time series, the Johansen (1988) likelihood estimator is applied. ${ }^{5}$ The results reported in Table 5 indicate more than one cointegrating equation. Cointegration among the time series justifies the use of the VEC model.

Table 6 presents the results of VEC model when expected real prices are assumed to be extrapolative. The error correction terms are reported in column one of Table 6 . The estimated t values are only significant for expected housing prices and employment, implying that only these variables respond to a previous period's deviation from the long-run equilibrium. The magnitudes of the error correction terms suggest that the extrapolative expected prices adjust much faster than the actual prices. Furthermore, a quick comparison of the error correction terms reported in Tables 3 and 6 indicates that extrapolative price expectations adjust much faster than expectations that are based on economic fundamentals. The log-likelihood ratios indicate that, although efficient with respect to information on employment, real housing prices can be predicted by the available information on price expectations, and real interest rates.

5 To judge the model adequacy against over and under fitted versions, the log-likelihood ratio test statistics is followed. The appropriate lag length is determined to be twelve. Results are available upon request. 


\section{Table 4}

Expected housing price based on past appreciation rates

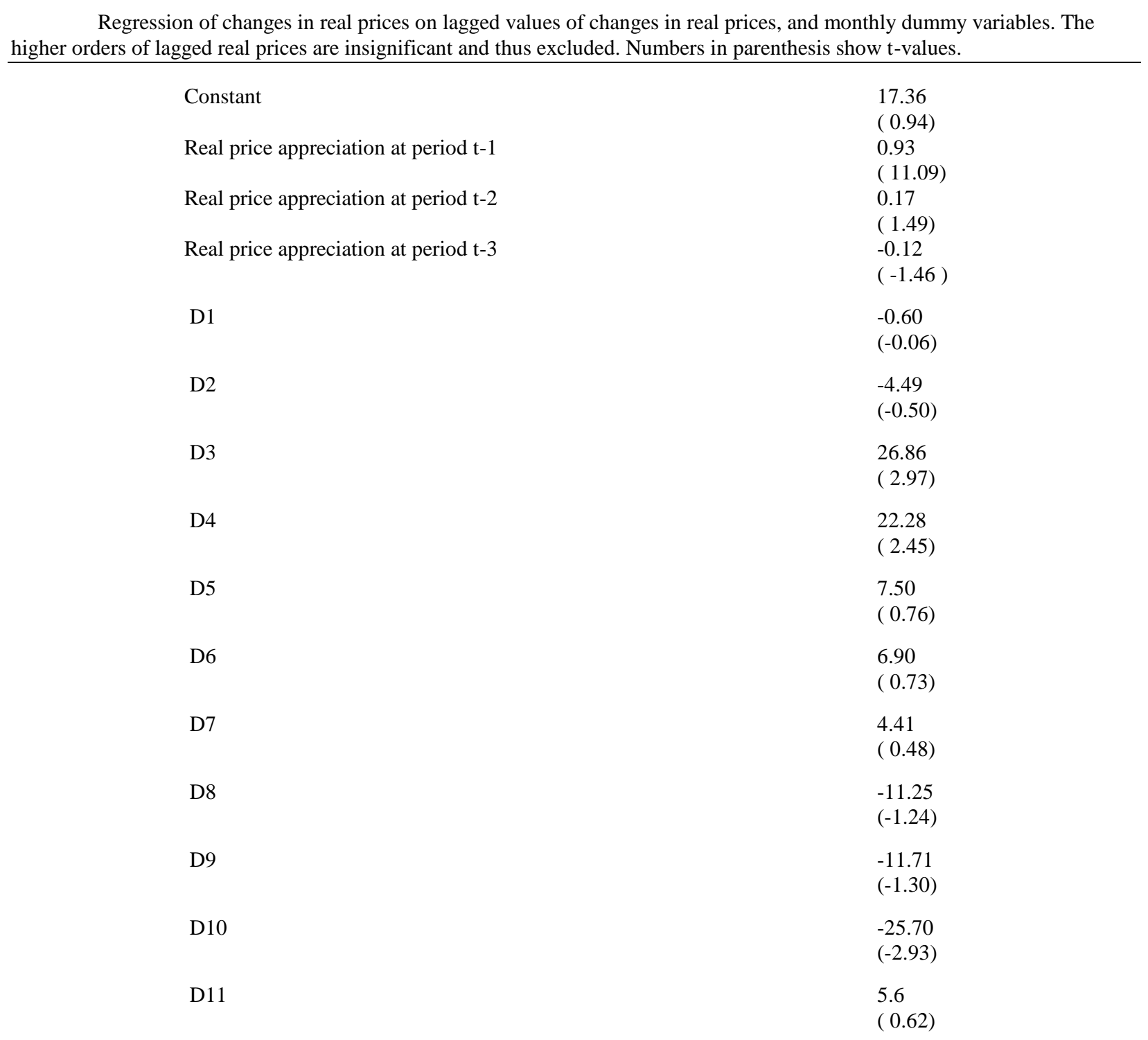

Adjusted R2

0.97

Table 5

Johansen Cointegration Test

Expected prices are based on the past appreciation rates

\begin{tabular}{ccc}
\hline $\begin{array}{c}\text { Likelihood } \\
\text { Ratio }\end{array}$ & $\begin{array}{c}\text { 5 percent Hypothesized } \\
\text { Critical value }\end{array}$ & No. Of cointegrating vectors \\
\hline & & None \\
156.08 & 62.99 & At most $1^{* *}$ \\
53.47 & 42.44 & At most 2 \\
13.49 & 25.32 & \\
\hline
\end{tabular}

** Denotes rejection of the hypothesis at 5\% significance level. The null hypothesis of at most two cointegrating vectors cannot be rejected at 5\%. Therefore, Likelihood Ratio test indicates 2 cointegrating equations at $5 \%$ level. 
Table 6

Temporal, Causality Tests from Error Correction Model with Expectation based on the Past Price Appreciations

The estimated error correction terms and log likelihood values to determine the efficiency in real estate market with respect to information on expected prices, real interest rates, and employment. The first column in the table shows the error correction terms and the $t$ values. Columns two through five present log-likelihood ratios, testing the hypothesis that past values of variable I do not have any effect on the $\mathrm{J}$.

\begin{tabular}{|c|c|c|c|c|c|}
\hline \multirow[b]{2}{*}{ Equations } & \multicolumn{4}{|c|}{ Lagged values of changes in } & \multirow[b]{2}{*}{ Emp } \\
\hline & $\mathrm{EC}$ & $\begin{array}{l}\text { Real housing } \\
\text { price }\end{array}$ & $\begin{array}{l}\text { Expected real } \\
\text { housing prices }\end{array}$ & $\begin{array}{l}\text { Real } \\
\text { interest rate }\end{array}$ & \\
\hline Real housing Price & $\begin{array}{l}10.36 \\
(1.66)\end{array}$ & ------- & $40.78 * *$ & $54.04 * *$ & 27.02 \\
\hline Expected prices & $\begin{array}{l}21.39 \\
(3.6)\end{array}$ & $89.48 * *$ & --------- & $54.09 * *$ & $29.09 * *$ \\
\hline Real interest rates & $\begin{array}{l}-0.13 \\
(-1.18)\end{array}$ & $92.83 * *$ & $98.01 * *$ & --------- & $29.09 * *$ \\
\hline Employment & $\begin{array}{l}43.70 \\
(2.45)\end{array}$ & 27.61 & 21.92 & $45.40 * *$ & --------- \\
\hline
\end{tabular}

Note: ** indicates the rejection of the null hypothesis that past values of variable I do not have any effect on the variable $\mathrm{J}$ at $5 \%$ level of significance.

Hence, the results refer to enhanced anomaly in the real estate market when expectations are formed by the extrapolation of past prices. These empirical findings strongly support the presumption of price run-ups that are driven by psychology and speculative behavior of homebuyers. Considering the large number of empirical evidence on housing market anomaly with respect to capital gain expectations, the results suggest that the extrapolative expectations can better explain the real estate price behavior than expectations formed by economic fundamentals. These findings support the argument by Abraham and Hendershott (1992) and Case and Shiller (1994) that capital gain expectations in the real estate market are extrapolative.

\section{CONCLUSION}

This paper investigates the sensitivity of market efficiency tests to expectation specifications in the real estate market. Using the Vector Error Correction Model (VECM), the paper studies the efficiency hypothesis, first under the assumption that future price expectations are formed by economic fundamentals, and next under the assumption that future price expectations are extrapolative. The data set incorporates monthly series on real median price of single-family houses in California, California employment rates, real interest rates, real income, and population.

A two-stage estimation procedure is carried out. In the first stage, the estimates of "expected" housing prices are generated under the two different assumptions mentioned above. In the second stage, applying VECM, the predictability of the housing prices with respect to capital gain expectation is examined under each expectation assumption.

The result suggests that housing prices are predictable with respect to capital gain expectations only when these expectations are specified as extrapolation of past appreciation. When capital gain expectations are assumed to be formed by the economic fundamentals, the null hypothesis that past expectations does not have any effect on current price cannot be rejected. Considering the significant empirical evidence on expectation-driven run-ups ${ }^{6}$, the results of this study suggests that the extrapolative expectation can explain the real estate price behavior more accurately than expectations that are formed by economic fundamentals.

${ }^{6}$ See Case and Shiller (1994) 


\section{REFERENCES}

1. Abraham, J. M. and P. H. Hendershott, 1992, Patterns and Determinants of Metropolitan House Prices, 1977 to 1991, In Browne, Lynn E. and Rosengren, Eric S., Editors, Real Estate and the Credit Crunch, Federal Reserve Bank of Boston Conference Series, 36, 18-42.

2. Abraham, J. M. and P. H. Hendershott, 1996, Bubbles in Metropolitan housing Markets. Journal of Housing Research 7, 191-207

3. Brueggeman,W. B., Chen, A. H. and T. G. Thibodeau, 1984, Real Estate Investment funds: Performance and Portfolio considerations, AREUEA journal 12, 333-354.

4. Case, K. E., 1986, The Market for Single-Family Homes in Boston, New England Economic Review 38-48

5. Case, K. E., and R. J. Shiller, 1988a, The Behavior of Home Buyers in Boom and Post Boom Markets, New England Economic Review, 29-46

6. Case, K. E., and R. J. Shiller, 1988b, Prices of single-family homes since 1970, New England Economic Review, 44-56.

7. Case, K. E., and R. J. Shiller, 1994, A Decade of Boom and Bust in the Prices of single Family Homes: Boston and Los Angeles, 1983 to 1993, New England Economic Review, 40-51.

8. Dusansky, R., and C. Koc, 2007, The capital gains effect in the demand for housing, Journal of Urban Economics 61, 287-298.

9. Dickey, D.A. and W.A. Fuller, 1997, Distribution of Estimation for Autoregressive Time Series with a Unit Root, The journal of American Statistical Association 74, 427-431.

10. Engle, R. F., and C. W. J. Granger, 1987, Co-Integration and Error Correction: Representation, Estimation, and Testing, Econometrica 55, 251-76.

11. Engle, R. F., and B. Yoo, 1987, Forecasting and Testing in Cointegrated Systems, Journal of Econometrics 35, 143-59.

12. Fama, E. F. and K. R. French, 1988, end Yields and Expected Stock Returns, Journal of Financial Economics 22, 3-25.

13. Hartzell, D. H. J. and M. Miles, 1986, Diversification Categories in Real Estate Investment, AREUEA Journal 14, 230-254.

14. Ho, M., and T. Kwong, 2002, Speculation and property price: chicken and egg paradox, Habitat International 26, 347-361.

15. Johansen, S., 1988, Statistical Analysis of Cointegration Vectors, Journal of Economic Dynamics and Control 12, 231-54.

16. Mankiw, N.G. and D. N. Weil, 1989, The baby boom, the baby bust, and the housing market, Regional science and urban economics 19, 235-258.

17. Meese, R. and N. Wallace, 1994, Testing the Present Value Relation for Housing Prices: Should I leave my house in San Francisco, Journal of Urban Economics 35, 245-266

18. Meese, R. and N. Wallace, 2003. House Price Dynamics and Market Fundamentals: The Parisian Housing Market. Urban Studies 40 (5-6), 1027-1045.

19. Park, J.K., Mullineaux, D.J. and I. K.Chew, 1990, Are Reits Inflation Hedges, Journal of Real Estate Finance and Economics 3, 91-103.

20. Riddel, M., 1999, Fundamentals, Feedback trading, and Housing Market Speculation: Evidence from California, Journal of Housing Economics 8, 272-284

21. Roche, M., 2001, The rise in house prices in Dublin: Bubble, fad or just fundamentals, Economic Modeling $18,281-295$.

22. Scott, L.O., 1990, Do Prices Reflect market Fundamentals in Real Estate Market, Journal of Real Estate Finance and Economics 3, 5-23.

23. Shiller, R. J., 1990, Speculative prices and Popular Models, Journal of Economic Perspectives, 55-65. 